\title{
CAMBRIDGE
}

\section{Antarctic Seals}

Research Methods and Techniques

Edited by R. M. LAWS

Foreword by DONALD B. SINIFF

The Antarctic is the world's most important habitat for seals, currently supporting more seals than all other parts of the world combined. As various national Antarctic programmes were established to study these animals, the need to standardize techniques became apparent. Antarctic Seals arising from work by the Scientific Committee on Antarctic Research, gives a detailed account of well-tried and agreed methodologies, techniques and rationale for the collection and initial analysis of data on the biology and population ecology of Antarctic seals. This volume will help facilitate comparisons between different regions of Antarctica, and will also provide a guide for those studying seals in other parts of the world and those carrying out research on other large mammal species.

f50.00 net HB $0521443024 \quad 412$ pp. 1993

For further information write to Giulia Williams at the address below. Please call 0223325970 to order any Cambridge book on your credit card.

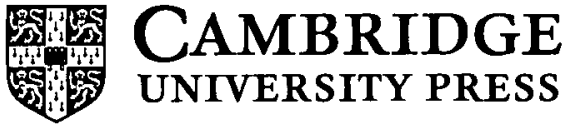

The Edinburgh Building, Cambridge CB2 2RU

\section{BELHA VEN/SPRI POLAR RESEARCH SERIES}

Published by Belhaven Press in association with the Scott Polar Research Institute

\section{Satellite remote sensing of polar regions \\ Robert A. Massom}

This volume describes the capture, processing, and use of images taken from satellites of the polar regions and their applications to the study of ice and snow, and of high-latitude meteorological, biological, and oceanic variables. It also provides a reference manual for all satellites from 1960.288 pages, illustrated, hardback. ISBN 1-85293-179-5.£39.50

\section{Arctic homeland: kinship, community and development in Northwest Greenland} Mark Nuttall

The Inuit of Greenland are a traditional people whose way of life and culture are under threat both from external pressures of 'development' and internal challenges to social cohesion. This study, based on extensive field research, examines the anthropology of the Inuit, the nature of their culture, their relationships with their meagre resource base, and their responses to change. A rich and vivid portrait of a little-known people. 196 pages, illustrated, hardback. ISBN 1-85293-225-2. £39.50.

\section{The myth of the explorer: the press, sensationalism, and geographical discovery} Beau Riffenburgh

Concentrating on the 'Golden Age' of exploration between 1855 and 1910, this book examines how the AngloAmerican press created the popular cult of the explorer, and how the insatiable appetite for adventure led to sometimes shabby actions as well as genuine bravery and scientific research. Based on extensive original research, the book reassesses many (not only polar) explorers' reputations and makes intriguing links between popular culture, the growth of science, imperialism, and the role of the press. 226 pages, illustrated, hardback. ISN 1-85293-260-0. $£ 39.50$.

Scott Polar Research Institute, University of Cambridge, Lensfield Road, Cambridge CB2 1ER, England. 


\section{CAMBRIDGE}

Now in paperback

\section{The Island of South Georgia} ROBERT HEADLAND

Foreword by SIR REX HUNT

This extensively illustrated book is the only comprehensive account of the island, combining historical, geographical, commercial, scientific and political events in a remarkable tour de force.

f19.95 net PB $0521424747 \quad 312$ pp. 1992

\section{Antarctic Fish and Fisheries}

KARL-HERMANN KOCK

A comprehensive description of Antarctic fish biology and ecology, considering the course of finfish exploitation and the present state of exploited fish stocks in the Southern Ocean. f55.00 net HB $0521362504 \quad 375$ pp. 1992 Studies in Polar Research

\section{THE \\ ANTARCTIC TREATY HANDBOOK}

(Seventh edition, October 1990)

\section{IS AVAILABLE FOR SALE FROM THE SCOTT POLAR RESEARCH INSTITUTE}

Edited by Dr J. Heap and published by the British Foreign and Commonwealth Office, the Antarctic Treaty Handbook reproduces material arising from Antarctic Treaty deliberations, including recommendations from consultative meetings and separate instruments dealing with seals, living resources, and mineral resources.

Now in four parts (not sold separately).

Part 1: General measures. Part 2: The Antarctic environment. Part 3: The Antarctic Protected Area System. Part 4: Other components.

Price $\$ 20.00$ (US\$40.00) including postage and packing. For second class air mail include £5.00 (US $\$ 10.00$ ) per copy extra.

\section{WORLD DATA CENTRE C GLACIOLOGY}

\section{*** New bibliography series ***}

\section{Series A: Glaciological Topics}

1. Ice and climate

2. Glacier advance and retreat

3. Ice coring and ice cores

4. Radio-echo sounding as a glaciological technique

5. Physics of ice

6. Chemistry of ice

7. Landice

8. Ice shelves

9. Sea, river and lake ice

10. Icebergs

11. Glaciohydrology

12. Snow cover and avalanches

13. Glacial geology and ice ages

14. Geocryology: permafrost and periglacial processes

15. Frozen-ground engineering

16. Icebreakers and ice-strengthened vessels

17. Navigation in ice-covered waters

\section{Series B: Regional Studies in Glaciology}

These can be compiled on any region of your choice. Some examples include: Glaciological research in Svalbard Glaciological research in the Antarctic

Peninsula

Bibliographies in Series A cost £25 each (academic rate £10). Prices vary for bibliographies in Series B with the number of records included. (Further information is available on request.)

To order a bibliography, please contact:

The Manager, WDC-C (Glaciology)

Scott Polar Research Institute

University of Cambridge

Lensfield Road

Cambridge CB2 1ER, UK 


\section{ARCTIC AND ALPINE RESEARCH}

INSTITUTE OF ARCTIC AND ALPINE RESEARCH · UNIVERSITY OF COLORADO AT BOULDER

Editor: Mark F. Meier

Managing Editor: Kathleen A. Salzberg

Arctic and Alpine Research is a quarterly international journal, now in its twenty-sixth year. It publishes original research papers, shorter contributions, correspondence, book reviews, and miscellaneous items of information. The subject matter deals with any scientific or cultural aspect of arctic and alpine environments and related topics on subarctic, subalpine, antarctic, subantarctic, and paleoenvironments. Papers are uni- or multidisciplinary but have interdisciplinary appeal. Symposia proceedings and monographs are also published from time to time, including the proceedings of the Comité Arctique International Seventh Conference, Reykjavik, Iceland, September 1986: Restoration and Succession in Circumpolar Arctic Lands (Vol. 19, No. 4, 1987), and Circumpolar Ecosystems in Winter, Churchill, Manitoba, February 1990 (Vol. 23, No. 1, 1991).

Recent issues have included papers on the following topics: Arctic hydrology; permafrost studies; glacier fluctuations; Holocene environments; Inuit use of sea ice; alpine grassland vegetation; lichen growth studies; subalpine forest growth.

Manuscripts in English should be submitted to the Managing Editor. Please write for instructions.

Terry V. Callaghan

Grange-over-Sands, U.K.

Chalmers Clapperton

Aberdeen, U.K.

William Fitzhugh

Washington, D.C., U.S.A.

Andrey Glazovskiy

Moscow, Russia

Richard K. Haugen

Hanover, New Hampshire, U.S.A.

\section{EDITORIAL ADVISORY BOARD}

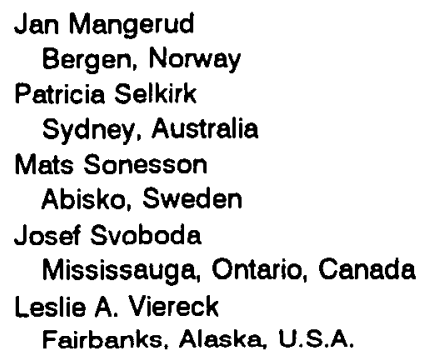

Peter Wardle

Christchurch, New Zealand

Patrick J. Webber

Hickory Corners, Michigan, U.S.A

Sidney E. White

Columbus, Ohio, U.S.A

Roman Zlotin

Moscow, Russia

\section{Subscription Rates, Vol. 26, 1994 (U.S. dollars)}

Library, \$75; Personal, \$50; Student and Retiree, \$35.

(Subscribers outside the United States, add $\$ 5$ for postage.)

Single issues: Library, $\$ 25$; Personal, $\$ 16.50$; Student and Retiree, $\$ 12$.

\section{ORDER FORM}

Please tick appropriate box and return to:

Arctic and Alpine Research, Institute of Arctic and Alpine Research, Campus Box 450, University of Colorado, Boulder, Colorado 80309-0450, U.S.A.

Name

Address

City

State

Zip/Post Code

Payment enclosed

VISA/MC

Send invoice

VISA/MC Account No Exp Date

Name as shown on card

Signature

Payment must be made in U.S. dollars on a U.S. bank, by international postal order, or by VISA/MasterCard. Please do not send personal checks from foreign countries. 


\section{Learn about the latest in POLAR BIOLOGY!}

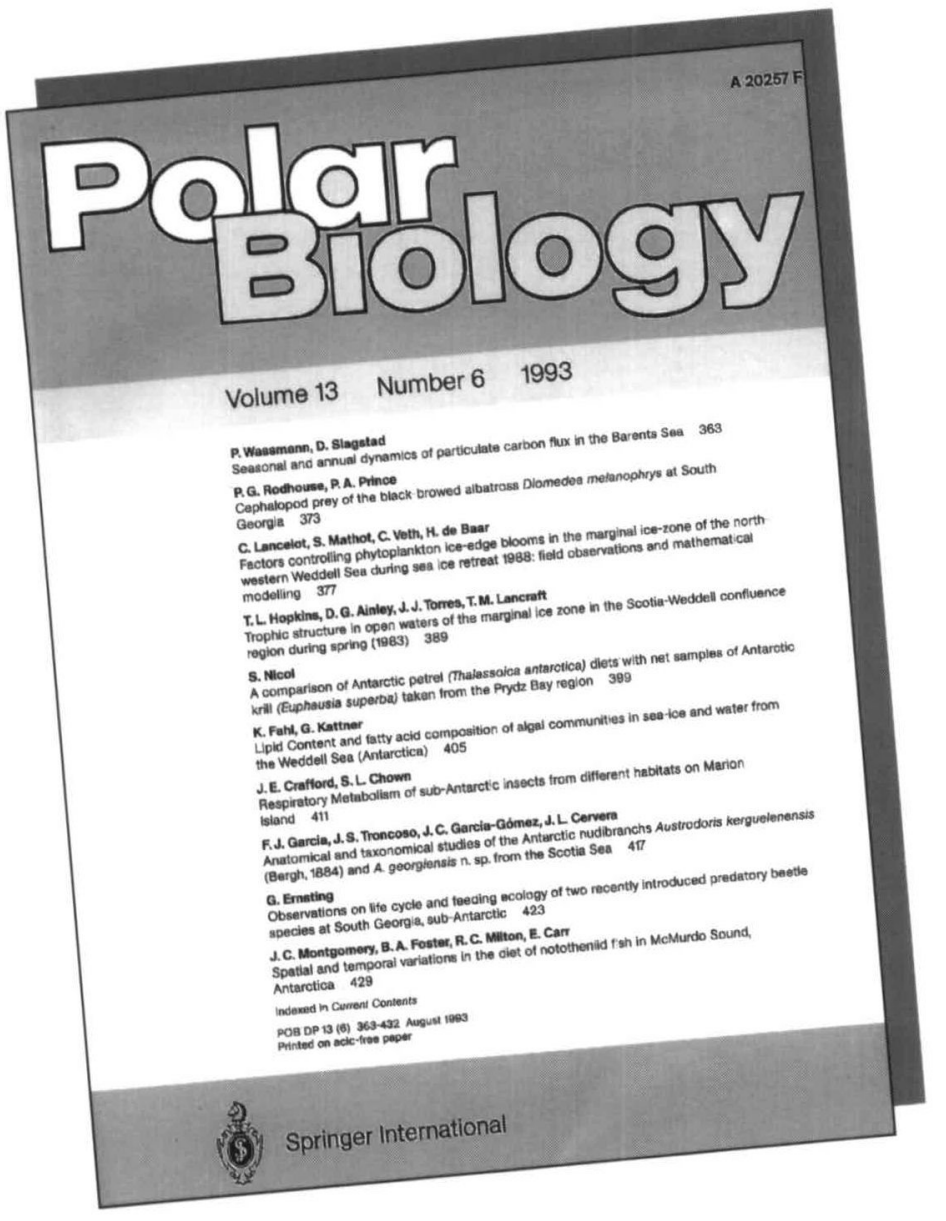

Polar ecosystems and the life of organisms in the extreme polar environment are of interest to an increasing number of scientists. Polar Biology is not only the focal point for scientists working in polar regions but also attracts the interest of those working in general biology, ecology and physiology, as well as in oceanography and climatology related to polar life.

Polar Biology presents results of all kinds of studies in plants, animals and micro-organisms of marine, limnic and terrestrial habitats of Arctic and Antarctic regions.

Topics covered include:

\section{- Life History}

- Ecology of Organisms and Communities

- Morphology and Taxonomy

- Distribution, Abundance and Biogeography

- Dynamics of Populations

- Physiology of Growth, Metabolism and Reproduction

- Behaviour and Sensory Physiology

- Ecosystem Studies

Managing Editor: G. Hempel, Kiel

Technical Editor: I. Hempel, Kiel

In cooperation with an international Editorial Board

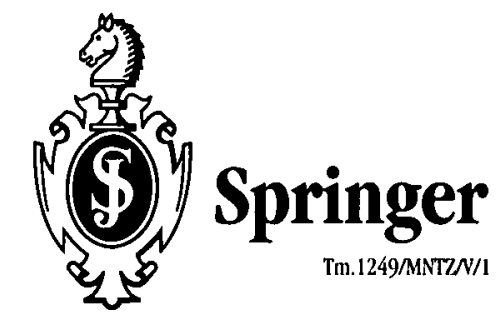

\section{ORDER FOR M}

$\square$ Please bill me

$\square$ Please charge my credit card

$\square$ Eurocard/Access/MasterCard

$\square$ American Express

$\square$ visa/Barclaycard/BankAmericard

$\square$ Diners Club

Number

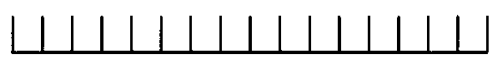

Valid until:

Please hand this order form to your bookseller or return to:

Springer-Verlag, Marketing Communication,

Postfach 1052 80, D-69042 Heidelberg, FRG

\section{Polar Biology ISSN 0722-4060 Titl №. 300}

$\checkmark$ Please enter my subscription beginning with 1994: Vol. 14 (8 issues) DM 948,- (suggested list price) plus carriage charges: FRG DM 29,20; other countries DM 38,-

$\checkmark$ Please send me a free sample copy

Name / Address

Date:

Signature:

Please note: I realize that I may cancel this order within ten days by writing to the address on the order form, whereby the postmark date will suffice as proof that the cancellation was made within the deadline. I confirm my understanding of this with my second signature.

$$
\text { 2nd Signature }
$$

All prices for books and journals include 7\% VAT. In EC countries the local VAT is effective. 


\section{ARCTIC ANTHROPOLOGY}

RETURN THIS AD AND RECEIVE A FREE SAMPLE ISSUE.

Editor: Richard G. Condon

Published: $2 / \mathrm{yr}$.

ISSN: 0066-6939

Devoted to the study of Old and New World northern cultures and peoples. Archaeology, ethnology, ethnohistory, linguistics, human biology and other related fields are represented.

Rates:

$\begin{array}{ll}\text { Individuals (must pre-pay): } & \$ 29 / \mathrm{yr} . \\ \text { Institutions: } & \$ 79 / \mathrm{yr} . \\ \text { Foreign postage: } & \$ 8 / \mathrm{yr} . \\ \text { Airmail: } & \$ 11 / \mathrm{yr} .\end{array}$

We accept MasterCard and VISA. Canadian customers please remit $7 \%$ Goods and Services Tax.

Please write for a free brochure and back issue list to: Journal Division, University of Wisconsin Press, 114 North Murray Street, Madison, WI 53715 USA

Or call, 608-262-4952, FAX 608-262-7560 


\section{POLAR RECORD}

VOLUME 30 NUMBER 172 JANUARY 1994

\section{CONTENTS}

\section{ARTICLES}

Fishing and conservation in southern waters. K-H. Kock $\mathrm{p} 3$

The practicalities of domestic legislation to prohibit mining activity in Antarctica: a comment on the Australian perspective. S. Blay and J. Green $\mathrm{p} 23$

Pesticide residues in the sediments from the lakes of Schirmacher Oasis, Antarctica. A. Sarkar, S.Y.S. Singbal, and S.P. Fondekar $\mathrm{p} 33$

Spying on the Russians: Archibald Douglas and HMS Egeria at Petropavlovsk, 1877-1878. I.R. Stone p 39

\section{NOTES}

The incomplete topographic mapping of Laurie Island, South Orkney Islands. J.F.D. Bridger $p 43$ Dens and summer pack size of Arctic wolves in Hold with Hope, East Greenland. U. Marquard-Petersen p 46

Microprobe analysis of trace metals in seal teeth from Svalbard, Greenland, and South Georgia. E. Cruwys, K. Robinson, and N.R. Davis p 49

\section{REVIEWS}

No ordinary journey: John Rae - Arctic explorer 1813-1893. I. Bunyan, J. Calder, D. Idiens, and B. Wilson. J.M. MacKenzie p 53. Antarctic microbiology. E.I. Friedmann (Editor). D.D. Wynn-Williams p 54. Dead silence: the greatest mystery in Arctic discovery. J. Geiger and O. Beattie. W. Barr p 56. The international law of Antarctica. E.J. Sahurie. S. Pannatier p 58. Antarctic fish biology: evolution in a unique environment. J.T. Eastman. G. Hubold p 59. Changing trends in Antarctic research. A. Elzinga (Editor). D.W.H. Walton p 60. Across the Keewatin icefields: three years among the Canadian Eskimos, 1913-1916. C. Leden. M.J. Whittles p 61. Maritime claims in the Arctic: Canadian and Russian perspectives. E. Franckx. D.R. Rothwell p 62. Canada's cold environments. H.M. French and O. Slaymaker (Editors). W.N. Mode p 63. The great Russian navigator, A.I. Chirikov. V.A. Divin. B.C. Imbert p 64. Fluctuations of glaciers 1985-90. W. Haeberli and M. Hoelzle (Compilers). J.A. Dowdeswell p 65. Advances in ice technology. T.K.S. Murthy, W.M. Sackinger, and P. Wadhams (Editors). D.S. Sodhi p 65. Brief reviews p 66

\section{OBITUARIES}

Walter A. Wood Jr p 67. Edward W. Bingham p 68

\section{MANUSCRIPT REFEREES}

1993 manuscript referees $p 71$

\section{INSTRUCTIONS FOR AUTHORS}

Instructions for authors $\mathrm{p} 72$

\section{SCAR BULLETIN No 112}

Council of Managers of National Antarctic Programmes (COMNAP), Report of Meeting, Christchurch, New Zealand, 21-25 June 1993 p 75

Standing Committee on Antarctic Logistics and Operations (SCALOP), Report of Meeting, Christchurch, New Zealand, 21-25 June 1993 p 76

Stations of SCAR Nations operating in the Antarctic, Winter 1993 p 78

\section{CAMBRIDGE} UNIVERSITY PRESS

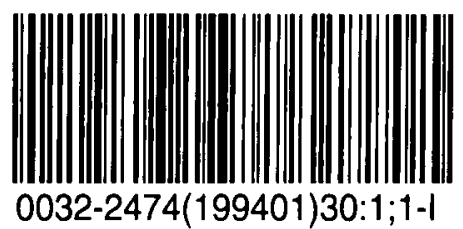

